\title{
Edukasi Bahaya Limbah Tekstil pada Kesehatan di MAS Al- Washliyah 22 Tembung
}

\author{
Rini Andarwati ${ }^{1}$ \\ 1Jurusan Farmasi Poltekkes Kemenkes Medan \\ E-mail: a.rini75@yahoo.com
}

\section{Irma Noviar ${ }^{3}$}

3Jurusan Farmasi Poltekkes Kemenkes Medan

E-mail: irmanoviarviar@gmail.com

\section{Zulfa Ismaniar Fauzi ${ }^{2}$}

2Jurusan Farmasi Poltekkes Kemenkes Medan

E-mail: zismaniar76@gmail.com

\section{Article History:}

Received: 2020-07-24

Revised: 2020-08-10

Accepted:2020-09-12
Abstract : The process of industrial pollution of hazardous and toxic waste (B3), especially in the textile industry, can occur directly or indirectly. The direct process is that the pollutant has a direct impact on poisoning so that it interferes with the health of humans, animals and plants or disrupts the ecological balance of water, air and soil. Indirect process, some chemical substances react in the air, water and soil, causing pollution. Batik waste also contains wax (wax). contains chemical compounds that are harmful to health, starting from itching on the skin, interfering with breathing, digestion and cancer. The purpose of this Community Service is to find out the description of knowledge about waste and its health hazards for students at MAS AlWashliyah 22 Tembung. The method used is a lecture about the impact of waste and its dangers on health and questions and answers as well as the provision of brochures and measuring instruments using $a$ questionnaire. The results of the measurement of knowledge before education resulted in good knowledge of 
Keywords : Education, Textil, Industrial polution

$60 \%, 20 \%$ enough and $20 \%$ less. After good education $75 \%$ and $25 \%$ enough. There is a significant relationship between before and after education $p=0.000$. The conclusion in this service activity is that there is an increase in students' knowledge after education.

Riwayat Artikel :

Diajukan: 03-13-2021

Diperbaiki: 10-01-2022

Diterima: 12-01-2022
Abstrak: Proses pencemaran limbah bahan berbahaya dan beracun (B3) industri khususnya pada industri tekstil dapat terjadi secara langsung maupun tidak langsung. Proses langsungnya adalah polutan berdampak langsung pada keracunan sehingga mengganggu kesehatan manusia, hewan dan tumbuhan atau mengganggu keseimbangan ekologi air, udara dan tanah. Proses tidak langsung, beberapa zat kimia bereaksi di udara, air dan tanah, menyebabkan polusi. Limbah batik juga mengandung lilin (wax). mengandung senyawa kimia yang berbahaya bagi kesehatan, mulai dari gatal-gatal pada kulit, mengganggu pernapasan, pencernaan dan kanker. Tujuan dari Pengabdian kepada Masyarakat ini adalah untuk mengetahui gambaran pengetahuan tentang sampah dan bahayanya bagi kesehatan siswa di MAS Al-Washliyah 22 Tembung. Metode yang digunakan adalah ceramah tentang dampak sampah dan bahayanya bagi kesehatan dan tanya jawab serta pemberian brosur dan alat ukur menggunakan kuesioner. Hasil pengukuran pengetahuan sebelum pendidikan menghasilkan pengetahuan baik $60 \%$, cukup $20 \%$ dan kurang $20 \%$. Setelah pendidikan baik $75 \%$ dan $25 \%$ cukup. Ada hubungan yang signifikan antara sebelum 
Kata kunci : Pendidikan, Tekstil, Polusi $\underline{\text { Industri }}$ dan sesudah pendidikan $p=0,000$.

Kesimpulan dalam kegiatan pengabdian ini

\section{Pendahuluan}

Permasalahan mengenai pengelolaan limbah dapat berdampak pada pencemaran lingkungan. Proses pencemaran industri limbah bahan berbahaya dan beracun (B3) terutama di industri tekstil dapat terjadi secara langsung maupun tidak langsung. Proses secara langsung yaitu bahan pencemar tersebut langsung berdampak meracuni sehingga mengganggu kesehatan manusia, hewan dan tumbuhan atau mengganggu keseimbangan ekologis baik air, udara maupun tanah. Proses tidak langsung, yaitu beberapa zat kimia bereaksi di udara, air maupun tanah, sehingga menyebakan pencemaran. Pencemaran ada yang langsung terasa dampaknya, misalnya berupa gangguan kesehatan langsung (penyakit akut), atau akan dirasakan setelah jangka waktu tertentu (penyakit kronik). Alam memiliki kemampuan sendiri untuk mengatasi pencemaran (self recovery), namun alam memiliki keterbatasan. Setelah batas itu terlampaui, maka pencemaran akan berada di alam secara tetap atau terakumulasi dan kemudian berdampak pada manusia, material, hewan, tumbuhan dan ekosistem (Ginting, 2007). Limbah dapat menyebabkan cacat fisik dan mental (Widowati et al., 2008). Bahayanya tingkat keracunan yang diakibatkan oleh limbah, ini sangat tergantung pada jenis karateristik limbah dalam waktu jangka pendek atau dalam jangka penjang. Kesemuanya ini diperlukan langkahlangkah mencegahnya, menanggulanginya, dan mengolahnya secara efektif.

Industri batik dan tekstil merupakan salah satu penghasil limbah cair yang berasal dari proses pewarnaan. Selain kandungan zat warnanya tinggi, limbah industri batik dan tekstil juga mengandung bahan bahan sintetik yang sukar larut atau sukar diuraikan (Suprihatin, 2014). Citrapancayudha dan Soetarto (2016) mengemukakan limbah batik juga mengandung lilin (wax). mengandung senyawa kimia yang membahayakan kesehatan dari mulai gatal pada kulit, mengganggu pernafasan, pencernaan dan kanker. Kegiatan pengabdian kepada masyarakat ini memiliki target pada siswa dan siswi Madrasah Aliyah Swasta (MAS) Al Washliyah 22 Tembung diharapkan agar menjadi agen 
perubah untuk memberikan informasi kepada keluarga maupun orang sekitar tentang bahaya limbah tekstil pada kesehatan agar dapat menambah pengetahuan mereka tentang bahaya limbah dan dampak bagi kesehatan serta cara pengolahannya

\section{Metode}

Edukasi dengan ceramah tentang dampak limbah dan bahayanya pada kesehatan dan tanya jawab serta pemberian brosur

Kegiatannya yaitu :

a. Perkenalan dan Promosi Politeknik Kesehatan dan Jurusan Farmasi

b. Pembagian kuesioner sebelum melakukan penyuluhan

c. Ceramah dan tanya jawab

Materi Penyuluhan disampaikan oleh Akademisi bidang Kesehatan Keselamatan Kerja (K3) pada Jurusan Farmasi Poltekkes Kemenkes Medan

d. Pembagian kuesioner sesudah penyuluhan

Para siswa diberi kuesioner dengan 15 pertanyaan dengan ketentuan menjawab benar skor 1 dan salah skor 0. Jika skor 11-15 kategori baik, skor 6-10 kategori cukup dan skor 0-5 kategori kurang.

\section{Hasil dan Diskusi}

Kegiatan ini terkait tugas Poltekkes Kemenkes Medan dalam melaksanakan Tri Dharma Perguruan Tinggi, salah satunya adalah melaksanakan pengabdian masyarakat. Rancangan Evaluasi dengan menggunakan Kuesioner yang berakitan dengan bahaya limbah. Kuesioner dibagikan sebelum dan setelah pelaksanaan edukasi.

Kegiatan berlangsung di MAS-AL Washliyah 22 Tembung, dengan menghadirkan 40 peserta (32 orang laki-laki dan 8 orang perempuan) dengan tetap mematuhi protokol kesehatan. Kegiatan ini dilakukan dengan metode Ceramah dan Diskusi sebagai upaya edukasi bahaya limbah tekstil. 
JURNAL ASTA

Abdi Masyarakat Kita

Vol. 02 No. 01, Januari 2022

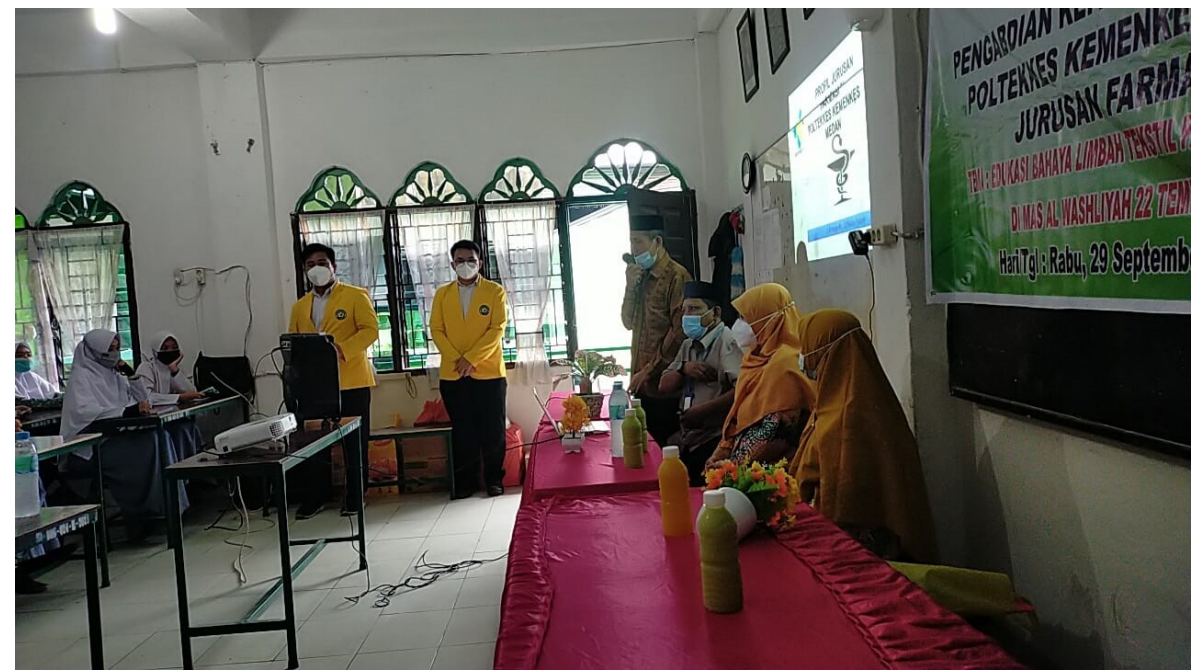

Gambar 1 : Kegiatan Sosialisasi Pengabdian Masyarakat

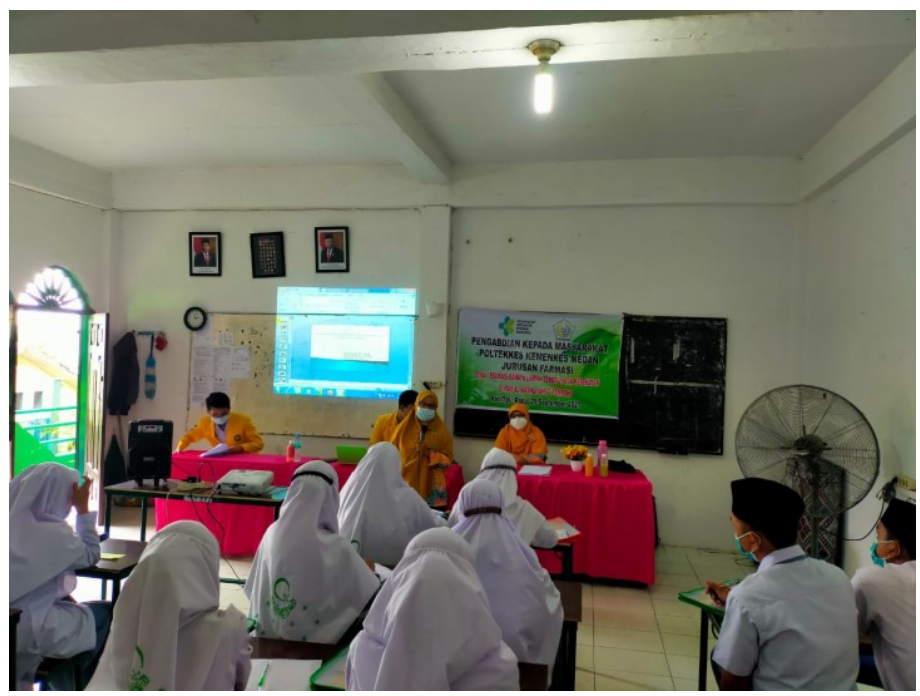

Gambar 2 : Pemaparan Materi Bahaya Limbah Tekstil

\section{Tingkat Pengetahuan Peserta}

Peningkatan pengetahuan dari sebelum ceramah kategori baik 24 orang (60\%) dan sesudah ceramah kategori baik 30 orang (75\%).

Tabel 1. Daftar Pertanyaan Kuisioner

No. Pertanyaan

1 Definisi limbah adalah : 
a. Buangan yang dihasilkan dari suatu proses produksi baik industri maupun domestik (rumah tangga).

2 b. Suatu proses produksi baik industri maupun domestik (rumah tangga).

Bentuk limbah berdasarkan senyawa zat kimia adalah

a. Rumah tangga

3 b. Organik dan non organic

Limbah yang berasal dari industri adalah:

a. Zat kimia

4 b. Sayur

Karakteristik limbah berdasarkan fisik dapat dilihat dari

a. Kadar oksigen

5 b. Bau

Karakteristik limbah berdasarkan biologi dapat dilihat dari

a. Bakteri

6 b. Kekeruhan

Limbah berasal dari industri dapat mengganggu kesehatan

a. Tidak

7 b. Ya

Dampak limbah terhadap lingkungan :

a. Penurunan kualitas air

8 b. Tempat berkembang biak bakteri

Dampak limbah terhadap kesehatan :

a. Penurunan kualitas air

9 b. Tempat berkebang biak bakteri

Limbah industri sebelum dibuang sebaiknya

a. Diolah dahulu

10 b. Dibuang ke saluran parit

Contoh limbah yang berrasal industri tekstil adalah

a. Zat warna

11 b. Sisa makanan 
Contoh limbah yang berrasal dari rumah tangga adalah

a. Zat warna

12 b. Sisa makanan

Pengolahan limbah dengan penyaringan termasuk cara :

a. Kimia

13 b. Fisika

Pengolahan limbah dengan menggunakan teknik bioremediasi termasuk cara:

a. Biologi

14 b. Kimia

Pengolahan limbah dengan koagulasi menggunakan ferrosulfat termasuk cara:

a. Biologi

15 b. Kimia

Salah satu contoh penyakit menular daampak limbah adalah

a. Kolera

b. Diabetes mellitus

Tabel 2. Master Tabulasi Hasil Pengukuran Sebelum dan Sesudah Edukasi

\begin{tabular}{cccccc}
\hline PESERTA & $\begin{array}{c}\text { JENIS } \\
\text { KELAMIN }\end{array}$ & $\begin{array}{c}\text { SKOR } \\
\text { PRE }\end{array}$ & KATEGORI & $\begin{array}{c}\text { SKOR } \\
\text { POST }\end{array}$ & KATEGORI \\
\hline 1 & P & 13 & Baik & 14 & Baik \\
2 & $\mathrm{~L}$ & 11 & Baik & 11 & Baik \\
3 & $\mathrm{P}$ & 12 & Baik & 14 & Baik \\
4 & $\mathrm{~L}$ & 13 & Baik & 14 & Baik \\
5 & $\mathrm{~L}$ & 13 & Baik & 15 & Baik \\
6 & $\mathrm{P}$ & 13 & Baik & 13 & Baik \\
7 & $\mathrm{P}$ & 10 & Cukup & 14 & Baik \\
8 & $\mathrm{P}$ & 11 & Baik & 13 & Baik \\
9 & $\mathrm{P}$ & 12 & Baik & 13 & Baik \\
10 & $\mathrm{P}$ & 13 & Baik & 13 & Baik \\
11 & $\mathrm{P}$ & 11 & Baik & 13 & Baik \\
12 & $\mathrm{P}$ & 10 & Cukup & 14 & Baik \\
13 & $\mathrm{P}$ & 14 & Baik & 13 & Baik \\
14 & $\mathrm{P}$ & 3 & Kurang & 9 & Cukup \\
15 & $\mathrm{P}$ & 11 & Baik & 12 & Baik \\
16 & $\mathrm{P}$ & 3 & Kurang & 6 & Cukup \\
17 & $\mathrm{P}$ & 14 & Baik & 15 & Baik
\end{tabular}


JURNAL ASTA

Abdi Masyarakat Kita

Vol. 02 No. 01, Januari 2022

\begin{tabular}{cccccc}
\hline 18 & P & 6 & Kurang & 11 & Baik \\
19 & P & 7 & Kurang & 12 & Baik \\
20 & L & 15 & Baik & 15 & Baik \\
21 & P & 3 & Kurang & 7 & Cukup \\
22 & P & 10 & Cukup & 14 & Baik \\
23 & L & 14 & Baik & 13 & Baik \\
24 & L & 10 & Cukup & 13 & Baik \\
25 & L & 12 & Baik & 15 & Baik \\
26 & L & 9 & Cukuo & 13 & Baik \\
27 & P & 10 & Cukuo & 11 & Baik \\
28 & P & 14 & Baik & 14 & Baik \\
29 & P & 14 & Baik & 13 & Baik \\
30 & P & 15 & Baik & 15 & Baik \\
31 & P & 15 & Baik & 15 & Baik \\
32 & P & 8 & Kurang & 12 & Baik \\
33 & P & 4 & Kurang & 6 & Cukup \\
34 & P & 15 & Baik & 15 & Baik \\
35 & P & 4 & Kurang & 6 & Cukup \\
36 & P & 12 & Baik & 13 & Baik \\
37 & P & 12 & Baik & 14 & Baik \\
38 & P & 2 & Kurang & 8 & Cukup \\
39 & P & 5 & Kurang & 8 & Cukup \\
40 & P & 3 & Kurang & 7 & Cukup \\
\hline TOTAL & & & 486 & \\
\hline
\end{tabular}

Keterangan:

Baik : 11-15, Cukup : 6-10, Kurang : 1-5

Tabel 3. Tingkat Pengetahuan Peserta

\begin{tabular}{ccccc}
\hline \multirow{2}{*}{ Kategori Pengetahuan } & \multicolumn{2}{c}{ Sebelum ceramah } & \multicolumn{2}{c}{ Sesudah ceramah } \\
\cline { 2 - 5 } & Jumlah & Persentase & Jumlah & Persentase \\
\hline 1. Baik & 23 & 58 & 32 & 80 \\
2. Cukup & 9 & 22 & 8 & 20 \\
3. Kurang & 8 & 20 & - & \\
\hline Total & 40 & 100 & 40 & 100 \\
\hline
\end{tabular}

Skor tingkat pengetahuan peserta terhadap bahaya limbah tekstil pada kesehatan adalah dengan kategori Baik meningkat hal ini didukung oleh tingkat pendidikan yaitu MAS serta 
cara penyuluhan dengan ceramah dan tanya jawab. Menurut Notoatmodjo, S., (2012) salah satu faktor yang mempengaruhi pengetahuan adalah a) tingkat pendidikan yaitu Pendidikan merupakan sebuah proses pengubahan sikap dan tata laku seseorang atau kelompok dan juga usaha mendewasakan manusia melalui upaya pengajaran dan pelatihan, maka jelas dapat kita kerucutkan bahwa sebuah visi pendidikan yaitu untuk mencerdaskan manusia. apabila seseorang yang mempunyai pendidikan yang tinggi akan mau menerima informasi yang baru. b). Paparan Informasi RUU teknologi informasi mengartikan informasi sebagai suatu teknik untuk mengumpulkan, menyiapkan, dan menyimpan, manipulasi, mengumumkan, menganalisa, dan menyebarkan informasi dengan maksud dan tujuan tertentu yang bisa didapatkan melalui media elektronik maupun cetak. c) Media contoh media yang didesain secara khusus untuk mencapai masyarakat luas seperti televisi, radio, koran, majalah, dan internet. Hal ini sesuai dengan hasil analisis data bahwa ada hubungan yang signifikan tingkat pengetahuan siswa sebelum dan sesudah diberikan intervensi edukasi bahaya limbah bagi kesehatan.

Paired Samples Corre lations

\begin{tabular}{|ll|r|r|r|}
\hline & \multicolumn{1}{|c|}{$\mathrm{N}$} & Correlation & \multicolumn{1}{c|}{ Sig. } \\
\hline Pair 1 & Pre \& Post & 40 & .899 & .000 \\
\hline
\end{tabular}

Paired Samples Statistics

\begin{tabular}{|c|c|c|c|c|c|}
\hline & & Mean & $\mathrm{N}$ & Std. Deviation & $\begin{array}{c}\text { Std. Error } \\
\text { Mean }\end{array}$ \\
\hline \multirow{2}{*}{$\begin{array}{l}\text { Pair } \\
1\end{array}$} & Pre & 10.1500 & 40 & 4.03542 & .63806 \\
\hline & Post & 12.1500 & 40 & 2.80613 & .44369 \\
\hline
\end{tabular}

Gambar 3 : 1) Hasil sebelum dan sesudah penyuluhan; 2) Hasil Analisis Data

Data kemudian di analisis menggunakan SPSS versi 20 dengan uji Paired Samples Statistics dan menunjukkan bahwa nilai korelasi antara sebelum dan sesudah test 0,899 artinya adanya hubungan yang kuat sebesar $89,9 \%$ dan nilai $p=0,000$ yang artinya ada hubungan signifikan pengetahuan siswa sebelum dan sesudah diberikan edukasi. 


\section{Kesimpulan}

Dari hasil pengabdian kepada masyarakat dapat disimpulkan bahwa Tingkat pengetahuan meningkat setelah dilakukan edukasi, ada hubungan yang signifikan tingkat pengetahuan siswa sebelum dan sesudah edukasi.

\section{Ucapan Terimakasih}

Kegiatan ini terselenggara berkat bantuan dan kerjasama dari: 1). Direktur Poltekkes Kemenkes Medan; 2). Kapus Penelitian dan Pengmas Poltekkes Medan; 3. Ketua Jurusan Farmasi Poltekkes Kemenkes Medan; 3). Tim Pengabdian Masyarakat; 4). Mahasiswa Jurusan Farmasi.

\section{Daftar Pustaka}

Al-Kdasi A, Idris A, Saed K, Guan CT, 2004. Treatment of Textile Wastewater by Advanced Oxidation Processes-A Review. Global Nest: The Int. J, 6(3), 222-230.

Asri. 2016. Dampak Limbah Dan Polusi Terhadap Manusia Dan Lingkungan. Allaudin University Press.

Citrapancayudha DR, Soetarto E, 2016. Biodegradation of Wax Residue on Semi-Solid Waste of Batik Industry by Bacteria. Proceeding Biology Education Conference, 13(1): 800806

Eskani NI, Carlo DI, Sulaeman S, 2005. Efektivitas Pengolahan Air Limbah Batik Dengan Cara Kimia Dan Biologi. Majalah Ilmiah Dinamika Kerajinan.Kementerian Perindustrian $17-27$

Glenn JK, Gold MH, 1983. Decolorization of Several Polymeric Dyes by the Lignin Degrading. Basidiomycetes Phanerochaete Chrysosporium.Appl. Environ. Microbiol. 45: 17411747

Noviar, I. 2019. Isolasi dan Potensi Bakteri Pendekolorisasi Limbah Perebusan Batik. Tesis. Medan

Machairiyah1, Zulkifli Nasution, Bejo Slamet. 2020. Pengaruh Pemanfaatan Lahan terhadap Kualitas Air Sungai Percut dengan Metode Indeks Pencemaran (IP). LIMNOTEK 27(1); 13-25 
JURNAL ASTA

Abdi Masyarakat Kita

Vol. 02 No. 01, Januari 2022

Munir E, 2006. Pemanfaatan Mikroba Dalam Bioremediasi: Suatu Teknologi Alternatif Untuk Pelestarian Lingkungan. Pidato Pengukuhan Jabatan Guru Besar Tetap Dalam Bidang Mikrobiologi FMIPA Universitas Sumatera Utara. Medan

Notoatmodjo, S. 2012. Kesehatan Masyarakat IImu dan Seni. Rineka Cipta

Saeni, 1989. Kesehatan Masyarakat Dan Teknologi Peningkatan Kualitas Air. Direktorat Teknologi Lingkungan

Setiono. 2001. Dasar Hukum Pengelolaan Limbah B3 dan Dampak Bagi Kesehatan di Wilayah Kenjeran. PLH Jawa Barat Kelas X Semester 1.

Suarsini E, Fidiastuti HR, 2017. Potensi Bakteri Indigen Dalam Mendegradasi Limbah Cair Pabrik Kulit Secara In Vitro. Bioeksperimen 3.(1).: 1-10

Suprihatin H, 2014. Kandungan Organik Limbah Cair Industri Batik Jetis Sidoarjo Dan Alternatif Pengelolaannya. Jurnal Kajian Lingkungan 2(2): 130-138

Widowati W, Sastiono A, Jusuf R, 2008. Efek Toksik Logam Pencegahan Dan Penanggulangan Pencemaran. Penerbit ANDI Yogyakarta

Winarno FG, 1984. Kimia Pangan Dan Gizi. Gramedia Pustaka Utama, Jakarta 